\title{
Ice-volume changes of selected glaciers in the Swiss Alps since the end of the 19th century
}

\author{
Andreas BAUDER, Martin FUNK, Matthias HUSS \\ Versuchsanstalt für Wasserbau, Hydrologie und Glaziologie, Eidgenössische Technische Hochschule Zürich (ETH), \\ CH-8092 Zürich, Switzerland \\ E-mail: bauder@vaw.baug.ethz.ch
}

\begin{abstract}
The evolution of surface topography of glaciers in the Swiss Alps is well documented with high-resolution aerial photographs repeatedly recorded since the 1960s and further back in time with topographic maps including elevation contour lines first surveyed in the mid-19th century. In order to quantify and interpret glacier changes in the Swiss Alps, time series of volume changes over the last 100-150 years have been collected. The available datasets provide a detailed spatial resolution for the retreat period since the end of the Little Ice Age. The spatial distribution as well as temporal variations of the thickness change were analyzed. A significant ice loss since the end of the 19th century was observed in the ablation area, while the changes in the accumulation area were small. We found moderate negative secular rates until the 1960s, followed by steady to positive rates for about two decades and strong ice loss starting in the 1980s which has lasted until the present. An evaluation of 19 glaciers revealed a total ice volume loss of about $13 \mathrm{~km}^{3}$ since the $1870 \mathrm{~s}$, of which $8.7 \mathrm{~km}^{3}$ occurred since the 1920s and $3.5 \mathrm{~km}^{3}$ since 1980. Decadal mean net balance rates for the periods 1920-60, $1960-80$ and $1980-$ present are $-0.29,-0.03$ and $-0.53 \mathrm{~m} \mathrm{a}^{-1}$ w.e., respectively.
\end{abstract}

\section{INTRODUCTION}

Mass changes of glaciers are considered to be a sensitive indicator for climatic variations (e.g. Houghton and others, 2001). Understanding the evolution and spatial variability of glaciers may contribute to better knowledge of impact, trends and rates of ongoing climate change. However, there are only a limited number of direct mass-balance observations available covering a relatively short period (SCNATETHZ, 1881-2002; Dyurgerov and Meier, 2005). The directly related information on volume changes, i.e. net balance (Paterson, 1994, p. 29), provides a good opportunity to quantify glacier changes over a larger area and time-span.

Thickness or volume changes may be derived from repeated comparison of the surface topography of different years. Digital elevation models (DEMs) describing the glacier surface geometry can be extracted by applying modern remote-sensing methods (Baltsavias and others, 2001) and evaluation of contour lines on topographic maps.

Most mountain glaciers and small ice caps showed significant mass loss during the second half of the 20th century (Dyurgerov and Meier, 2000; Ohmura, 2004). A change in trend was observed in the time series in the mid1970s, followed by a more rapid loss of ice volume in the last two decades. Glacier retreat in the Swiss Alps since the end of the Little Ice Age around 1850 is estimated at $700 \mathrm{~km}^{2}$ in area and $50-60 \mathrm{~km}^{3}$ in volume (Müller and others, 1976; Maisch and others, 1999; Paul and others, 2004). Significant thickness changes have been reported from both mountain glaciers and polar ice sheets (Echelmeyer and others, 1996; Arendt and others, 2002; Rignot and Thomas, 2002; Rignot and others, 2003).

In the course of ongoing glacier monitoring in Switzerland (SCNAT-ETHZ, 1881-2002) glaciers have repeatedly been surveyed in detail, and high-resolution glacier maps have been produced (e.g. Mercanton, 1916; Kasser and Röthlisberger, 1966). These investigations are complemented by the well-documented glacier surface geometry on historical maps (the so-called Siegfried maps) generated in the second half of the 19th century and the first complete survey of official national maps 1:50000 in the first half of the 20th century.

Since the 1960s, aerial photographs have been taken at regular intervals in Switzerland in order to update the national maps. Additionally, high-resolution aerial photographs exist for selected glaciers, some at annual intervals (SCNAT-ETHZ, 1881-2002). Several projects carried out by the Versuchsanstalt für Wasserbau, Hydrologie und Glaziologie (VAW) of ETH Zürich in collaboration with public administrations and private companies have contributed substantially to the documentation of glacier surface geometry (many unpublished reports).

In this study, we present a compilation of ice volume changes for a selection of glaciers, with detailed information on the surface topography for five to six specific points in time within the last 100-150 years. The spatial distribution as well as temporal variations of the thickness change were analyzed. The main goal was to determine decadal net volume changes and to both identify and interpret differences on a regional scale in the Swiss Alps. Similar investigations have been conducted in the Austrian Alps for the three decades 1950-79 (Finsterwalder and Rentsch, 1981).

\section{METHODOLOGY}

The comparison of repeated surveys of glacier surface topography has traditionally been applied to evaluate mass balance indirectly (e.g. Hoinkes, 1970; Paterson, 1994). This method cannot be used to obtain mass balance of annual resolution and therefore replace in situ measurements (Fountain and others, 1999; Bauder, 2001). Glacier mapping has been mainly used to confirm results from direct massbalance measurements (Haakensen, 1986; Cox and March, 2004). Due to significant progress in remote-sensing technologies, DEM generation has become a standard tool. 


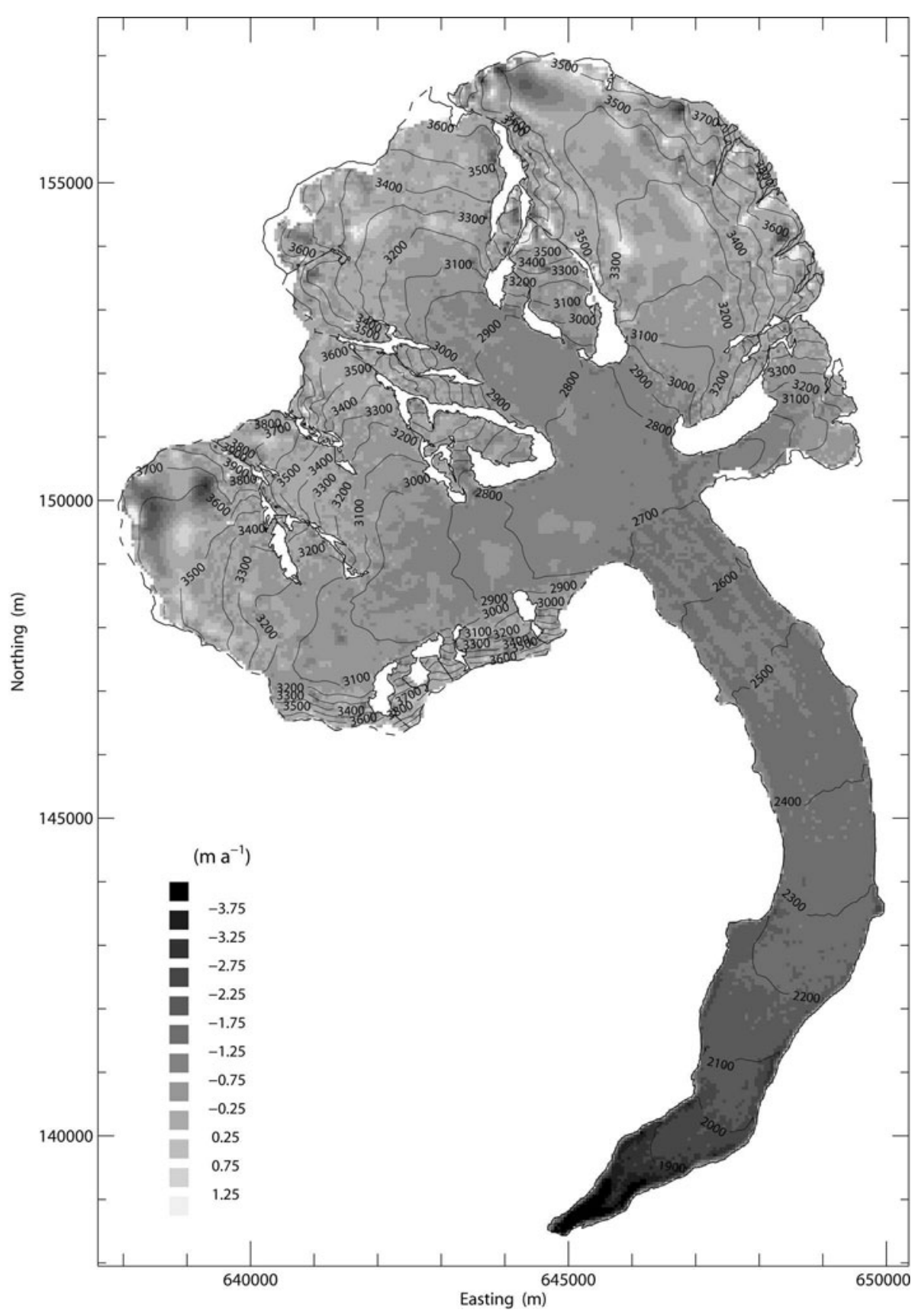

Fig. 1. Spatial distribution of thickness change (in m ice) of Grosser Aletschgletscher in the period 1980-99.

We limited our investigations to available aerial photographs or special glacier maps with clearly identifiable production procedures and survey dates. In order to extend our time series further back in time, we resorted to older maps mainly from the Siegfried survey between 1860 and 1890. Where possible we used originals (so called plane-table sheets) from the field surveys.

\section{Digital photogrammetry}

Digital stereophotogrammetry is applied for the analysis of the aerial photographs and DEM extraction. We used the LHS DPW 770 system (SOCET SET ${ }^{\circledR}$ ). Image orientation includes bundle adjustment of a set of special marked ground-control points. A two-step processing procedure was developed. The automatic extraction of the first step was refined with manual post-processing in order to eliminate erroneous measurements and to fill gaps where the automatic run was not successful.

\section{Maps}

All maps used are in the offcial Swiss coordinate system (Swiss geodetic datum CH1903). Old maps from the 19th century refer to an older elevation base, which was accounted for. Scanned maps were geo-referenced and rectified first with an equally distributed and glacieroverlapping reference grid. Contour lines have been digitized manually.

\section{Accuracy check}

Surrounding non-glacierized areas are included in both photogrammetrical analysis and contour line evaluation, enabling independent control points and smooth transition 


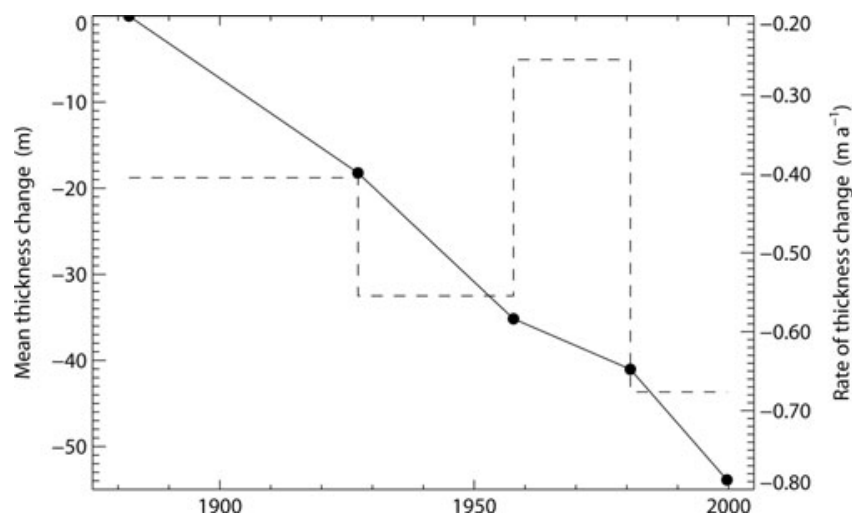

Fig. 2. Evolution of cumulative thickness change (solid line) and rate of thickness change (dashed line) of Grosser Aletschgletscher.

at the glacier boundary. With flight heights typically in the order of 1000-3000 m over the surface, an accuracy in elevation of $<0.3 \mathrm{~m}$ of the photogrammetrical analysis may be expected. Successive photogrammetrical analyses have been checked against one another by comparing the control points. In addition, identical points outside the glacier provide an independent validation. Differences are within the expected accuracy, and no systematic trend or measurement error was found.

Digitized contour lines of the surrounding area have been superimposed where possible. Due to differences in elevation base and contour interval, the possiblities were limited. Surrounding non-glacierized areas are often characterized by steep rock walls where the mapping accuracy is generally lower. An additional set of features (e.g. mountain peaks, ridges and buildings) on the different maps have been compared. Resulting borderlines of the 19th-century maps were superimposed directly into the photogrammetrical analysis software and obvious errors were eliminated.

\section{DEM interpolation and comparison}

In order to compare two DEMs, the results of photogrammetric analysis and evaluation of the contour lines have to be interpolated on regular grids. Interpolation of clustered data is a challenging task, and several algorithms exist. We applied the GTGRID 2.0 routines of the PV-WAVE software package (Visual Numerics, Inc., 2001), specifically developed routines for topography interpolation. This algorithm is based on least-squares fit of radial-basis functions, and additional effort is made to minimize the extrapolation of excessive gradients due to noise or input points that are very close together. A grid spacing between 10 and $50 \mathrm{~m}$ was chosen, depending on the resolution of input data and glacier size.

Volume changes are calculated in the common glacierized area covered by the two DEMs under comparison. The volume of the completely melted or accumulated ice masses in one of the DEMs is then added or subtracted, respectively. The definition of glacier boundaries involves some arbitrary decisions as to what area to include depending on whether the determination of volume changes is basin-wide or limited to continuous parts of the glacier. We restricted our investigations to the principal and connected areas. In firn areas at the transition of the glacier to steep firn-covered walls, the boundary follows the bergschrund. For some glaciers an arbitrary boundary had to be defined in order to
Table 1. Compilation of glaciers used in this study with area, evaluated period, number of individual DEMs, cumulated total icevolume change and mean net balance

\begin{tabular}{|c|c|c|c|c|c|}
\hline \multirow[t]{2}{*}{ Glacier } & Area* & $\begin{array}{c}\text { Investigated } \\
\text { period }\end{array}$ & $\begin{array}{l}\text { Number } \\
\text { of DEMs }\end{array}$ & $\begin{array}{l}\text { Volume } \\
\text { change }\end{array}$ & \multirow{2}{*}{$\begin{array}{c}\text { Net } \\
\text { balance } \\
\mathrm{m} \mathrm{a}^{-1} \text { w.e. }\end{array}$} \\
\hline & $\mathrm{km}^{2}$ & & & $10^{9} \mathrm{~m}^{3}$ & \\
\hline Allalin & 9.680 & 1932-2004 & 7 & -0.108 & -0.13 \\
\hline Basòdino & 2.201 & 1929-2002 & 7 & -0.061 & -0.25 \\
\hline Chessjen & 0.195 & 1879-2004 & 7 & -0.037 & -0.34 \\
\hline Clariden & 5.127 & 1936-2003 & 4 & -0.040 & -0.20 \\
\hline Corbassière & 15.996 & 1877-2003 & 4 & -0.421 & -0.15 \\
\hline Giétro & 5.549 & 1934-2003 & 5 & -0.068 & -0.09 \\
\hline Gorner & 38.247 & 1931-2003 & 3 & -1.694 & -0.27 \\
\hline Gries & 5.264 & 1884-2003 & 9 & -0.621 & -0.59 \\
\hline Grosser Aletsch & 83.015 & 1880-1999 & 5 & -4.858 & -0.42 \\
\hline Hohlaub & 2.256 & 1879-2004 & 7 & -0.094 & -0.23 \\
\hline Limmern & 2.415 & 1876-1977 & 3 & -0.129 & -0.38 \\
\hline Plattalva & 0.864 & 1947-1977 & 2 & -0.005 & -0.38 \\
\hline Rhone & 16.450 & 1874-2000 & 6 & -0.588 & -0.24 \\
\hline Schwarzberg & 5.332 & 1879-2004 & 7 & -0.136 & -0.15 \\
\hline Seewjinen & 1.538 & 1956-2004 & 4 & -0.021 & -0.17 \\
\hline Silvretta & 2.893 & 1893-2003 & 7 & -0.085 & -0.20 \\
\hline Trift & 15.335 & $1861-2003$ & 8 & -0.680 & -0.27 \\
\hline Unteraar & 22.727 & 1880-2003 & 7 & -1.729 & -0.44 \\
\hline \multicolumn{6}{|l|}{ Unterer } \\
\hline Grindelwald & 20.600 & 1861-2004 & 4 & -1.560 & -0.39 \\
\hline
\end{tabular}

*Area at the end of investigated period.

minimize discrepancies of unmatching marginal boundaries. For net balance evaluation, the glacierized area in one or the other DEM is used. We assume a constant ice density of $900 \mathrm{~kg} \mathrm{~m}^{-3}$.

\section{RESULTS}

As one example of the 19 glaciers (see Table 1) that have been studied, the results of Grosser Aletschgletscher, the largest glacier in the Alps, are presented. We have chosen the sub-period 1980-99 to highlight the comparison of the two successive DEMs.

In Figure 1 the spatial distribution of the thickness change is shown. A typical pattern was found. Thickness changes are small in the accumulation area, and the largest changes occur at the glacier snout. In the ablation area, there is a gradual increase starting from the equilibrium line, cumulating at the current glacier snout and decreasing again toward the former snout. A much larger scatter is found in the accumulation area. The observed general pattern of thickness change is typical for both a retreating and advancing glacier.

The evolution of the mean thickness change for the investigated 120 year period (1880-1999) shows a significant ice loss of $>50 \mathrm{~m}$ mean thickness (see Fig. 2). Also given in Figure 2 are the rates of mean thickness change for each sub-period.

Calculated decadal net balance rates of all investigated glaciers for each sub-period are contrasted in Figure 3. Varying lengths of sub-periods, with an increasing resolution in the last 30 years, are clearly visible. The general overall trend of negative rates is interrupted by one or two subperiods of mass gain around 1960-85. Exceptions to this are the large glaciers (e.g. Grosser Aletschgletscher, Unteraargletscher) and glaciers where this specific time period is not 


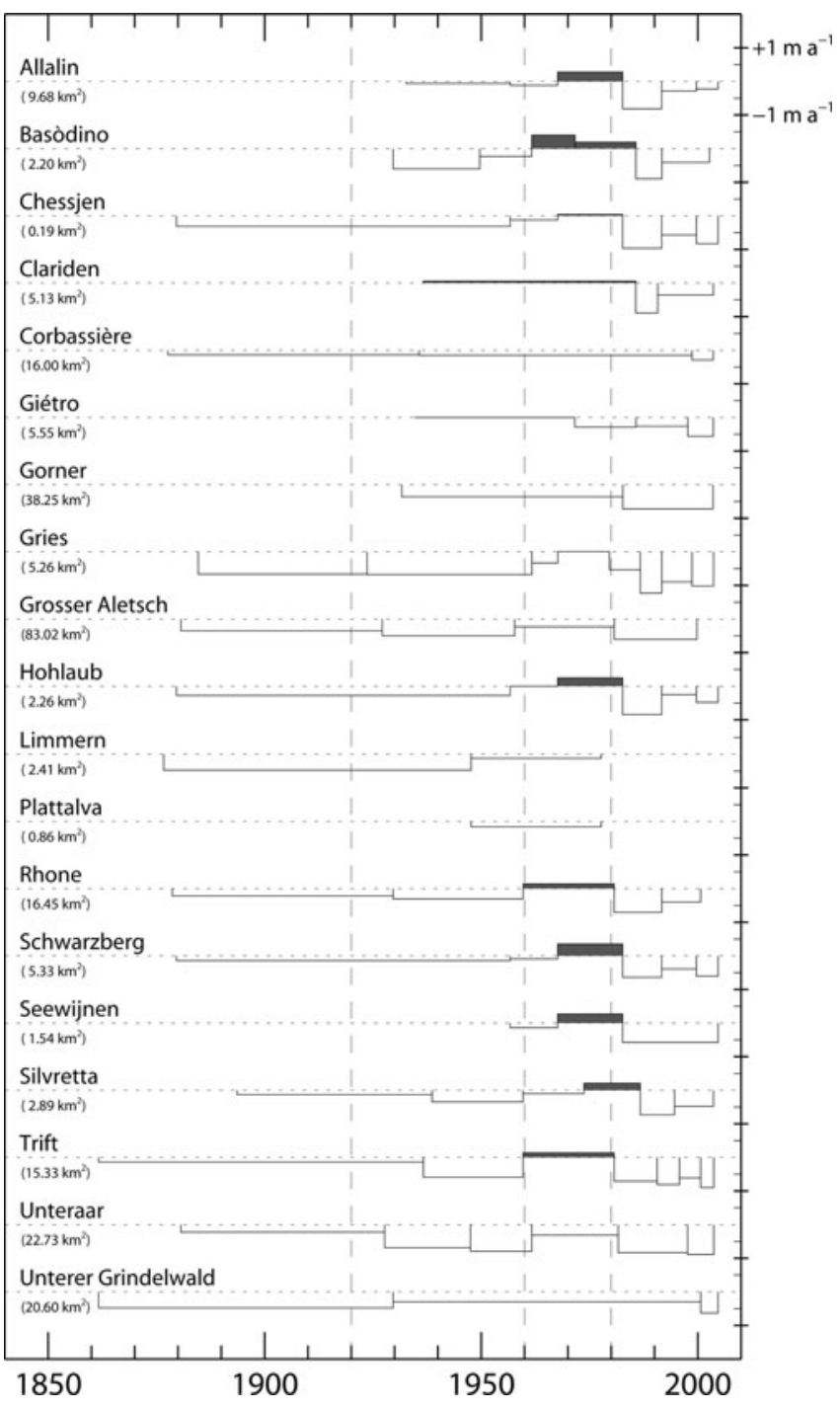

Fig. 3. Decadal net balance rates. The vertical dashed lines indicate the periods since 1920 used for the analysis of mean rates.

sufficiently resolved by individual sub-periods. The corresponding values of total ice volume change and derived mean net balance can be found in Table 1 .

The overall error in total volume change is difficult to estimate. There are three dominant contributions: (1) error in map survey, (2) accuracy of contour line evaluation or photogrammetric analysis, and (3) error due to interpolation on a regular grid. The first contribution is difficult to quantify, but limited analyses obtain values in the orders of meters to tens of meters depending on the quality of the maps. The second type of error is evaluated to be $0.3 \mathrm{~m}$ for the photogrammetric analysis and 0.5-2.5 m depending on map scale, respectively. The third type of error is the smallest at $0.05 \mathrm{~m}$, but detailed analysis showed significant differences between the relatively smooth glacierized surface and complex topographic structures. The total error of the estimated mean volume change is within $5 \%$ for most cases. Exceptions may result for small glaciers with inaccurate old maps or short periods of successive DEMs. The accuracy is better in the ablation area than in the accumulation area where changes are bigger and the texture is more distinct. In addition, errors in an individual DEM will be corrected by earlier or later DEMs in the time series and do not affect the total volume change.

\section{DISCUSSION AND CONCLUSIONS}

The DEMs were chosen not only to reach far back in time but also to resolve observed advancing and recession periods (SCNAT-ETHZ, 1881-2002). Whereas the period of steady to positive evolution during the 1960s-80s and the subsequent period of distinct mass loss are clearly displayed, our dataset is not yet detailed enough to clarify previous periods more specifically. All of the investigated glaciers show a similar evolution of the net balance rate, except Glacier du Giétro, where mass loss by break-off plays an important role until the 1970s. This glacier is situated in a lateral hanging valley. In the past, it repeatedly built up unconnected ice dams at the bottom of the main valley during advance periods (Raymond and others, 2003). The glacier snout remained constant at the valley edge, and during advance ice broke off and no significant thickness change occurred in the ablation area. The resulting evolution of volume changes completes this picture.

The quality of the 19th-century maps (Siegfried survey) varies significantly. Many of these maps had to be rejected because the surface topography was insufficiently accurate. In some cases, a visual inspection revealed discrepancies, and comparison of successive DEMs provided an unambiguous test by evaluating the resulting spatial distribution of the thickness changes. Maps dating between 1920 and 1940, belonging to the first survey of the official Swiss map series, are of the required accuracy and are of unique value for glaciological reconstruction of former surface topography. The scale of the maps used in this study varies between $1: 2000$ and $1: 50000$, resulting in large differences in the contour-line interval and accuracy of the DEM that may be obtained.

Many maps of the official series at scales 1:50000 and $1: 25000$ published by the Swiss Federal Office of Topography (swisstopo) exist, and have recently become available as digital products. However, a lot of care in the application is needed because updates are usually only made where changes are large, and the glaciers are not completely surveyed. In addition, the data of the mapped state is hardly known. So for our purpose the available accuracy is often insufficient.

The assumption of a constant ice density is reasonable if no major change in the firn layer is expected. Our results clearly show that thickness changes are generally small in the accumulation area, and we expect that the firn-layer thickness will remain constant even over long timescales. This is supported by direct point-based observations on Grosser Aletschgletscher or Claridenfirn (SCNAT-ETNZ, 1881-2002). The shifting of the firn/ice transition and the firn line was limited in the past but may become more important as complete meltout repeatedly occurs due to rapid downwasting.

Our datasets cover an area of $255.7 \mathrm{~km}^{2}$ compared to an estimated total area of $1285.7 \mathrm{~km}^{2}$ in the 2000 inventory of the Swiss Alps (Paul and others, 2004). The calculated total volume loss of $12.96 \mathrm{~km}^{3}$ since the mid-19th century is underrated due to sparse datasets of the 19 selected glaciers, but relative values will give an indication on the changes involved. From the 1920 s onward, a period covered by most of the individual time series, a volume loss of $8.73 \mathrm{~km}^{3}$ resulted, of which $3.45 \mathrm{~km}^{3}$ (40\%) has occurred since 1980 . For the periods 1920-60, 1960-80 and 1980-present, the decadal mean net balance rates are $-0.29,-0.03$ and 
$-0.53 \mathrm{~m} \mathrm{a}^{-1}$ w.e., respectively. These values clearly illustrate the temporal variation of the thickness change evolution. Our results agree with a similar study of selected Austrian glaciers for the period 1950-79 (Finsterwalder and Rentsch, 1981) and a recent compilation of averaged observations of mass-balance time series for the whole Alps since 1960 (Dyurgerov and Meier, 2005).

The selected glaciers in our study are geographically distributed over the major glacierized region of the Swiss Alps and reflect the spatially uneven distribution of large and small glaciers. Although there are marked differences between individual glaciers, there is no geographic pattern in the volume loss visible.

To complete our effort to establish time series of volume changes since the end of the Little Ice Age in the second half of the 19th century, a more extensive analysis of inadequate maps is needed. Our results indicate fewer problems on larger glaciers where bigger changes occur. The smaller glaciers, located mostly in remote areas, were given less careful attention by the surveyors.

Our analyses provide the baseline for further investigations of a reconstruction of a mass-balance time series of annual to seasonal resolution. A combined approach using an accumulation and melt model and validation with cumulative total volume changes seems to be a promising approach.

\section{ACKNOWLEDGEMENTS}

This study is the result of the contribution to Swiss glacier monitoring made by VAW for many years. We are indebted to B. Nedela for painstaking work in digitizing old topographic maps, and to $\mathrm{H}$. Bösch for providing DEMs. We also thank swisstopo and R. Hübscher for aerial photographic surveys. We thank R.S.W. van de Wal (scientific editor), M. Dyurgerov and an anonymous reviewer for helpful comments. M. Phillips improved the English.

\section{REFERENCES}

Arendt, A.A., K.A. Echelmeyer, W.D. Harrison, C.S. Lingle and V.B. Valentine. 2002. Rapid wastage of Alaska glaciers and their contribution to rising sea level. Science, 297(5580), 382-386.

Baltsavias, E., E. Favey, A. Bauder, H. Boesch and M. Pateraki. 2001. Digital surface modelling by airborne laser scanning and digital photogrammetry for glacier monitoring. Photogramm. Rec., 17(98), 243-273.

Bauder, A. 2001. Bestimmung der Massenbilanz von Gletschern mit Fernerkundungsmethoden und Fliessmodellierungen: eine Sensitivitätsstudie auf dem Unteraargletscher. Mitt. VAW/ETH 169.

Cox, L.H. and R.S. March. 2004. Comparison of geodetic and glaciological mass balance techniques, Gulkana Glacier, Alaska, USA. J. Glaciol., 50(170), 363-370.

Dyurgerov, M.B. and M.F. Meier. 2000. Twentieth century climate change: evidence from small glaciers. Proc. Natl. Acad. Sci. USA (PNAS), 97(4), 1406-1411.
Dyurgerov, M.B. and M.F. Meier. 2005. Glaciers and the changing Earth system: a 2004 snapshot. Boulder, CO, Institute of Arctic and Alpine Research. (INSTAAR Occasional Paper 58.)

Echelmeyer, K.A. and 8 others. 1996. Airborne surface profiling of glaciers: a case-study in Alaska. J. Glaciol., 42(142), 538-547.

Finsterwalder, R. and H. Rentsch. 1981. Zur Höhenänderung von Ostalpengletschern im Zeitraum 1969-1979. Z. Gletscherkd. Glazialgeol., 16(1), 111-115.

Fountain, A.G., P. Jansson, G. Kaser and M. Dyurgerov. 1999. Summary of the Workshop on Methods of Mass Balance Measurements and Modelling, Tarfala, Sweden August 10-12, 1998. Geogr. Ann., 81A(4), 461-465.

Haakensen, N. 1986. Glacier mapping to confirm results from mass-balance measurements. Ann. Glaciol., 8, 73-77.

Hoinkes, H. 1970. Methoden und Möglichkeiten von Massenhaushaltsstudien auf Gletschern: Ergebnisse der Messreihe Hintereisferner (Ötztaler Alpen) 1953-1968. Z. Gletscherkd. Glazialgeol., 6(1-2), 37-90.

Houghton, J.T. and 7 others. 2001. Climate change 2001: the scientific basis. Contribution of Working Group I to the Third Assessment Report of the Intergovernmental Panel on Climate Change. Cambridge, etc., Cambridge University Press.

Kasser, P. and H. Röthlisberger. 1966. Some problems of glacier mapping experienced with the 1:10000 map of the Aletsch glacier. Can. J. Earth Sci., 3(6), 799-809.

Maisch, M., A. Wipf, B. Denneler, J. Battaglia and C. Benz. 1999. Die Gletscher der Schweizer Alpen: Gletscherschwund 1850, Aktuelle Vergletscherung, Gletscherschwund-Szenarien 21. Jahrhundert. Zürich, vdf Hochschulverlag AG ETH Zürich. (Schlussbericht NFP 31.)

Mercanton, P.L. 1916. Vermessungen am Rhonegletscher / Mensuration au glacier du Rhône: 1874-1915. Neue Denkschr. Schweiz. Naturforsch. Ges. 52.

Müller, F., T. Caflisch and G. Müller. 1976. Firn und Eis der Schweizer Alpen: Gletscherinventar. Zürich, Eidgenössische Technische Hochschule. (Geographisches Institut Publ. 57.)

Ohmura, A. 2004. Cryosphere during the twentieth century. In Sparling, J.Y. and C.J. Hawkesworth, eds. The State of the Planet: Frontiers and Challenges in Geophysics. Washington DC, American Geophysical Union, 239-257.

Paterson, W.S.B. 1994. The physics of glaciers. Third edition. Oxford, etc., Elsevier.

Paul, F., A. Kääb, M. Maisch, T. Kellenberger and W. Haeberli. 2004. Rapid disintegration of Alpine glaciers observed with satellite data. Geophys. Res. Lett., 31(21), L21402. (10.1029/ 2004GL020816.)

Raymond, M., M. Wegmann and M. Funk. 2003. Inventar gefährlicher Gletscher in der Schweiz. Mitt. VAW/ETH 182.

Rignot, E. and R.H. Thomas. 2002. Mass balance of polar ice sheets. Science, 297(5586), 1502-1506.

Rignot, E., A. Rivera and G. Casassa. 2003. Contribution of the Patagonian icefields of South America to sea level rise. Science, 302(5644), 434-437.

Swiss Academy of Sciences and ETH Zürich (SCNAT-ETHZ). 18812002. The Swiss glaciers. Zürich, Swiss Academy of Sciences. Glaciological Commission; Federal Institute of Technology (ETH). Laboratory of Hydraulics, Hydrolology and Glaciology (VAW). (Glaciological Report Nos. 1-122.)

Visual Numerics, Inc. 2001. PV-WAVE technical reference manual. Seventh edition. Boulder, CO, Visual Numerics, Inc. 